\title{
Rural Microcredit: Evidences From Albania
}

\author{
Egerta Marku, PhD candidate
}

University of Tirana, Albania

doi: 10.19044/esj.2016.v12n10p104 URL:http://dx.doi.org/10.19044/esj.2016.v12n10p104

\begin{abstract}
The purpose of this paper is to analyse the issues and concerns of Albanian rural credit, which is a powerful tool for enhancing production and productivity and for poverty alleviation. Further it highlights some of the strategies adopted by the Albanian government to increase the rural credit facilities in the rural area of Albania.

The various problems faced by the farmers in applying for loans are analysed in detail. Rural credits serve as a tool for providing a sustainable livelihood for people who lives in these areas. Several organisations and Microfinance Institutions,. are playing a major role in providing rural credit facilities to rural Albania. to make the rural credit facilities available to most of the needy. In spite of several efforts put up by various organisations to increase the rural credit facilities, several challenges will prevail in the years to come.These aspects of the financial sector remain undervalued in mainstream literature on rural credit. With Albania being a nation in which more than 40 percent of people live in rural areas and rural credit being a powerful, and the only, tool for rural people in providing a means of livelihood, its importance and potential should be known to each individual.
\end{abstract}

Keywords: Credit, Rural, Rural Regions, Poverty, Albania

\section{Introduction}

Access to finance is critical for the growth of the agriculture sector. The shift from subsistence to commercial agricultural production requires funds. However, in developing countries, where agriculture is a source of livelihood for 86 per cent of rural people (International Finance Corporation [IFC], 2013), financing for investments in agriculture is scarce, even for large investors.

The need for investing in agriculture is increasing due to a rising global population and changing dietary preferences of the growing middle class in emerging markets toward higher value foods (e.g. dairy, meats, fish, fruits, vegetables, etc.). 
Banking sectors in developing countries lend a much smaller share of their loan portfolios to agriculture compared to agriculture's share of GDP. This limits investment in agriculture by both farmers and agro-enterprises. It also demonstrates that the barrier to lending isn't due to a lack of liquidity in the banking sectors, but rather a lack of willingness to expand lending to agriculture.

A productive resource such as agricultural credit is very vital for efficient and sustainable production activities especially in developing countries (Nweke, 2001). Farm credit is among the essential factors needed for agricultural production, and with it, farmers can secure farm inputs such as; farm equipments and hired labour (Odoh, 2009). Farm credit is widely recognized as one of the intermediating factors between adoptions of farm technologies and increased farm income. It is one of the fundamental ingredients of sustainable agricultural production; as such its accessibility and demand is among the prerequisites for attaining the national goal of reducing rural poverty and ensuring self sufficiency in food production.

\section{Challenges of Agricultural Financing:}

Similar to other sectors, those who invest in agriculture, particularly local farmers, but also foreign-owned plantations, processing factories, storage facilities or fertilizer companies, may need funds from third parties to carry out their businesses. However, in the current global financial system, a number of factors frustrate the development of solid financial services in rural areas in most developing countries. First, transaction costs in rural areas are higher than in urban areas due to a more dispersed population with weak infrastructure (International Fund for Agricultural Development [IFAD], 2009a). Second, and more importantly, the risk factors inherent in agriculture often inhibit financial institutions from lending. These include production risks linked to natural hazards (such as droughts, floods and pests), farmers weak ability to provide collateral (either because the farmer lacks title to land to offer as a loan guarantee or the value of the land may be too low) and the volatility of prices (IFAD, 2009a). Third, the financial sector may not be sophisticated enough in some developing countries. The availability and innovation on sector-specific financial instruments and services is usually poor.

Also, although financial services may be available, they may not be suitable for all types of agricultural activities, which will have diverse needs with respect to timing for disbursements, amounts and risks, among others. For example, in seasonal farming, funding is needed in particular stages of the production process (IFAD, 2009a). At the same time, the offer of financial products may only be available to large-scale farming operations 
with sound track records, and therefore may not meet the specific needs of the client.

Finally, the lack of records and statistics on farming in developing countries makes assessment of credit suitability challenging for financial providers. This changes the conditions required to access financial products and undermines opportunities for profitable investment.

\section{Who Needs Finance in the Agriculture Sector?}

Agriculture encompasses a broad range of activities from small-scale farming to infrastructure projects to research and development. As a result, when referring to agriculture finance, the market clusters it in four groups. The groupings correspond to different approaches to addressing the needs of the sectors: (1) the needs of farmers and entrepreneurs, (2) the transactions between the actors along the value chain, (3) infrastructure needs and (4) generating knowledge to support the sector.

1. Farmers and small agricultural entrepreneurs: This approach is focused on the actors in the agriculture sector that need financing. Farmers and small entrepreneurs, like small supply companies, need finance to allow them to expand production and/or diversify products. This can include, for example, finance for inputs (such as seeds and fertilizers), production (such as machinery and equipment) and marketing (such as processing, packaging and transport) (Food and Agriculture Organization [FAO] \& World Bank, 2013).

2. Actors along the value chain: The focus is on the links between different actors along a value chain. Agriculture entails a sequence of interlinked activities - transactions - in a chain that starts from the supply of seeds and fertilizers and finishes in the mouth of the consumers (IFAD, 2012). There are financial instruments specifically designed to strengthen these links between the actors along the value chain.

3. Rural infrastructure: Financing can be also concentrated on the infrastructure needed to carry out agricultural activities. The sector depends heavily on infrastructure such as rural transport systems, irrigation systems, water supply, sanitation, electricity, storage and telecommunication facilities. These projects are costly and require large amounts of financing.

4. Research and Development (R\&D): This last approach focuses on financially supporting knowledge generation for the sector. This includes the generation of agricultural technology and new technical knowledge about products, processes and services for the sector. (R\&D also provides valuable knowledge to help producers prepare business plans for banks or other financial institutions, to support financial planning and credit assessment by financial institutions, and government planning in general. 


\section{Farmers and Small Agricultural Entrepreneurs Characteristics in Albania}

With the privatization of land in 1991, the dominant business model in the Albanian agricultural production is agricultural family farms. There are a small number of agricultural cooperatives but their importance is almost negligible. Among the key factors that influence the development of family farms, we can mention: a) the small size of individual plots of land available, and $b$ ) the high degree of fragmentation of farms

Table 1: household farms in Albania

\begin{tabular}{|c|c|c|}
\hline Denomination & 2012 & 2014 \\
\hline Number of farms & 350.916 & 352.315 \\
\hline The average farm size (ha) & 1.17 & 1.16 \\
\hline
\end{tabular}

Source: ISTAT June 2015

Agriculture does not reflect the government's strategies for establishing cooperatives and large farm and the production continues at low levels in small areas. According to agricultural and livestock statistics (2014), there is an increase in the number of farms by $0.4 \%$ compared with a year ago, coupled with the decline in average farm size of $0.6 \%$. So, the number of farms in 2012 was 350,916, while in 2014 rose to 352 315. These increase in the number of farms could come as a result of their formalization and this was accompanied by fragmentation of agricultural land. The average farm size in 2014 resulted 1:16 ha, from 1:17 ha in 2012

According to INSTAT statistics, about $82 \%$ of family farms use machines for land preparation and the remaining $18 \%$ use manual labor or animals. In terms of operative cost, 93\% of family farms use chemical fertilizers. This is the highest block individual costs used in the production cycle. Other costs include the purchase of seeds, irrigation, renting of machinery etc. The main agricultural products are cereals (mainly wheat), vegetables, potatoes and beans. While cereals are grown for personal consumption, vegetables, potatoes and fruits are mainly intended for the market. In general, most of the farms in Albania still suffer low efficiency of their activities and the "disconnect" from agro processing industry. Typically, farmers in Albania are at the same time the manufacturer, shipper and seller of their products. In most cases preventing them from concentrating on real activities: agriculture, time and effort used to bring products to market and selling them include opportunity costs. The lack of separation between production and sales, contributing to a lower competitiveness of farms nationally and internationally. Moreover, Albanian farmers suffer by increased competition from neighboring states as a result of the Free Trade Agreement. While access to the EU market has been given since the signing of the Stabilization and Association Agreement in 2006, 
most farmers are not able to export to the EU because of strict security standards applied in the EU food.

\section{Problems Faced by Farmers in Applying for Loans in Albania:}

The agricultural sector in Albania is a sector with many problems and challenges, and not all farmers can apply for loans due to a number of conditions, demands to be met. First, it is the sector with the highest risk compared with other sectors, the lack of infrastructure, natural factors, to which agricultural production is very sensitive (floods, frosts, strip etc.), this type of risk is difficult to measure and be fully evaluated by a financial institution. This risk is accompanied by lack of insurance schemes for natural agribusinesses to these sensitivities. If these schemes would be present, it would be an encouraging sign for the banking system and will be more readily related to the establishment of enterprises with the agriculture and agribusiness sector. Second, agricultural businesses generally lack the financial and managerial documentation for the banking sector poses a high risk. Banks require more financial stability, more financial information and information about business performance, as well as investment plans and how this investment would be used. Thirdly, the problem is land ownership. Albanian farmer operates sized plots of land on 1.2 hectares (below the European average), this limited size brings inability advantages benefits in economies of scale, which would increase production or reduce costs and business units. Only those who have large areas of land may acquire further loans, while most of them have owned land fragmented as a result of the fall of communism and the dissolution of agricultural cooperatives. Consequently the cost of production is higher. Due to the high cost of the process of lending, banks are less willing to launch high-cost procedures for small amounts. Another problem from the viewpoint of financial institutions is the lack of guarantee for the service requested, since the inability to cover the demands for guarantees not to commit forces businesses to develop their investment. Lack of collateral is one of the reasons why banks are not interested to invest in farming business. Fourth, the small percentage of profit is another problem in granting credit, as every agricultural activity considered at risk in terms of its settlement. Seasonal production is one of the reasons for this uncertainty. Fifth, agricultural activities are considered by banks as short-term and less stable, and therefore credit conditions are not favorable for the broad mass of producers.

Despite numerous problems which faces the process of lending to the agricultural sector, this sector has great potential for development. Agricultural businesses must optimize their production processes, processing and collection of raw materials, investing in technology efficient, with low fuel consumption (electricity) and high performance. In accordance with the 
cycle of production, agribusiness working capital needs, to better manage workflow and cash flow for the business. Increased investment in this sector comes from increased demand in the market for agricultural products, increased demand for export of local products.

\section{The Role of Government in Financing Agriculture:}

Information constraints do not immediately justify direct government interventions in the market, because markets may be efficient constrained, that is, they maximize incomes subject to the information and other barriers that participants face. For example, in rural areas, poverty, low population density, isolated markets, seasonality, and highly covariant risk such as widespread crop failures often result in high transaction costs, a lack of traditional collateral, variable incomes, and limited opportunities for diversifying risk. These features differentiate rural financial markets from urban ones and often scare off traditional for-profit financial intermediaries. They do not, however, present market failures, because these features that result in high real costs to society are also faced by government interventions.

The case for direct interventions depends on whether the objective is general rural income expansion or targeted poverty reduction. Careful analyses that identify market failures and specify their causes should precede appropriate interventions to expand rural incomes. Even if a market failure is identified, direct interventions (through subsidies, credit programs, or institutions) are warranted only if the market failure can be addressed cost effectively; thus, the benefits must exceed the costs. Although policy and regulatory reforms that promote growth are often the most promising way to reduce rural poverty as well, special interventions may be required if economic growth is not appropriately shared. These interventions are justified based on social norms rather than on market failures and target optimal income distribution or guarantee a minimum standard of living to the under privileged.

To support the agricultural sector and establish incentives for investment, there were several Albanian governments subsidized scheme applied in encouraged the planting of fruit trees, olives and grapes (2007). The grant made available in 2008 , rose in value (10 million dollars) and offered support to the livestock sector (in the form of a fixed payment per head of pure race of cows), organic production, irrigation in orchards. Criteria for the allocation of subsidies, were the size of the farm sector, these although were often controversial criteria for transparency and favoritism subjectivisms in the decision making. This year (2016) the Ministry of Agriculture has made profound changes in schemes of support for female, where more space is given to the scheme "Support 50\% of the investment", 
which has as its main focus, setting up collection points to agricultural and livestock products; their processing as well as large farms. Support schemes aimed at formalizing the Albanian agriculture, employment, exports and economic growth. They support agricultural production delivery and collection points, infrastructure for collection, preservation, processing and marketing of products; innovation and technology investment for agriculture, quality assurance and product standards; support for ruminants, based on tradition and competitive advantages of our country. The money is given in the form of grants after the farmer has completed investments.

The recent initiative of the Ministry of Agriculture, farmer subsidized production delivered, setting a limit production, will guide them in creation of joint units in a tribe or society groupings parcels adjacent to increase quotas production, otherwise the number of those who will benefit from the subsidy will be very small. Those who have little land, are exempt from the criteria. Thus, tacitly started disappearance of small farms or farm units which are in terms of survival. The authorities are in favor of the creation of cooperatives and large farms, but without clarifying exactly how it will happens. In the government's decision of January 2015, the procedures for granting of subsidies and the amount of the acquisition, the main criterion is the area of land planted. So, gaining funds having more farm land. According to the decision, the farmer must have not less than 0.5 hectares of land planted to become beneficiaries.

A subsidy is to support the delivery of production of fruits and vegetables in the collection or processing issues, $15 \%$ of the value of goods sold, verified with the tax bill. The amount of delivery is: not less than 30 quintals and no more than 300 quintals of fruits; for not less than 50 quintals and no more than 400 quintals of vegetables. At this point it should be clarified that there are few farm families that have so many manufacturing. To be part of such aid must be completed before other obligations, such as paying land tax for 2015, payment of bills, all to be equipped with TIN (taxpayer identification number).

\section{Conclusion}

Access to finance is a vital part of any developed agriculture sector, and drawing farmers and small entrepreneurs in developing countries into the financial system is far from accomplished.

It requires a combination of good laws, a specialized financial sector and profitable businesses of small and large farmers and companies in the agriculture sector. Innovation in finance to solve the needs of the rural sector should not be limited to financial institutions. The government can play a proactive role by promoting laws and regulations with new financial instruments or even raising awareness of existing ones to bring them to the 
attention of the financial and agricultural sectors. Specialization in agricultural finance in the government and in the financial sectors is an important driver to its development. However, financing is not a charitable activity; it is primarily profit driven. This necessarily means that all possible regulation and programs to attract financing must be realistic with the characteristics of the sector and the viability and rate of return. Managing the risks and understanding the opportunities of the agriculture sector is key for any successful policy or law. Thus, to attract finance and, consequently, investment in the agriculture sector, it is critical to strengthen both the agriculture and financial sectors.

\section{References:}

(2009, October). Rural Finance: Small Amounts Making a Big Difference . IFAD.

Center, R. F. (2013). An Analytical Framework for Regulation and Supervision of Agricultural Finance. Rome, Italy: FAO.

D.W.Adams. (1995). Using Credit Unions as Conduits for Microenterprises Lending: Latin American Insights . ILO Working Papers on Enterprise and Cooperative Development, Poverty Oriented Banking.

Development, O. f. (2010). Facilitating Access to Finance, Disscussion Paper on Credit Guarantee Schemes. OECD.

Fleisig Heywood, N. d. (1996). Creating a Legal and Regulatory Framework to Promote Access to Rural Credit . Washington D.C: Center for the Economic Analysis of Law.

Instituti i Statistikave. (2016, Prill 5). Retrieved from www.instat.gov.al.

Miller, C. (2004). Twelve Key Challenges in Rural Finance. FAO.

Rahmah, K. A. (1977). Poverty and Landlessness in Rural Asia. Geneva: International Labor Organization.

Robinson, M. (2001). The Microfinance Revolution. Washington DC: World Bank.

www.azhbr.gov.al. (2016, Mars 5). Retrieved from Agjencia pwr Zhvillimin Bujqesor dhe Rural.

www.ruralfinance.org/fileadmin/templates/rflc/documents/6_financing_smal lholder_web.pdf. (2013). Financing Smallholder Agricultural Term Investments. FAO \& World Bank.

Yaron, J. (1992). Successful Rural Finance Institutions. Discussion Paper 150 . Washington DC: World Bank. 